\title{
Money Market Instruments and Financial Deepening in the Nigeria Emerging Economy
}

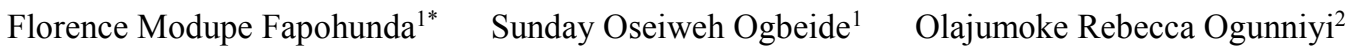 \\ 1.Department of Accounting and Finance, Faculty of Social and Management Sciences, Elizade University, \\ Ilara- Mokin, Ondo State, Nigeria \\ 2.Department of Accounting, Faculty of Management Sciences, Federal University Oye- Ekiti, Ekiti State,
} Nigeria

\begin{abstract}
The study examined money market instruments and financial deepening in the context of an emerging economy like Nigeria. The study used money market instruments like Treasury bills (TBs), Bankers' acceptances (BAs), Certificate of deposits (CDs) and Commercial papers (CPs). The ratio of money supply to gross domestic product was a proxy for financial deepening. Time series data was generated from Central Bank of Nigeria Statistical Bulletins in the period 1981 to 2016 for the study. Preliminary tests including Augmented Dickey Fuller (ADF), unit root test and descriptive statistics were carried out before the main econometric procedures were employed to analyze the data. The econometric procedures carried out include granger causality test, the ordinary least square multivariate regression method; the Johansen co-integration and the error correction mechanism methods (ECM). The study found strong effect of money market instruments on financial deepening in Nigeria in the long run. Granger causality test result revealed no directional causality relationship between Treasury bills and financial deepening, while bi-directional causality exists between Certificate of deposits and financial deepening; unidirectional causality exists between Bankers' acceptances, Commercial papers and financial deepening. The study recommends that policies that promote trading in international money market instruments like Bankers' acceptances should be strengthened by the Federal government of Nigeria to deepen the financial market as well as enhance the competitiveness of the Nigerian money market in the global market. This should consequently translate to financial deepening in Nigeria and improvement of the economy at large.
\end{abstract}

Keywords: Financial Deepening, Treasury Bills, Bankers' Acceptances, Certificate of Deposits and Commercial Papers.

JEL CLASSIFICATION: M10

DOI: $10.7176 /$ RJFA/10-16-07

Publication date: August $31^{\text {st }} 2019$

\section{Introduction}

Money market as a segment of the financial markets is a market for short-term investments and in the promotion of liquidity. The existence of a well functioning money market is fundamental for safe income producing channel for short-term investments of funds both for banks and firms as well as for enhancement of quick liquidity (Igbinosa \& Orobator, 2016). They opine that a highly developed money market is an essential prerequisite for the efficiency of monetary policy in a deregulated financial environment with the Central Bank having to increasingly use direct tools of monetary control such as open market operations to equilibrate the demand and supply for bank reserves. According to Mohammed (2014), the existence of money market engenders trading in short-term instruments to meet short needs of large users of funds such as the government, banks and large corporate organizations. Money market instruments are tools for trading in the money market. They facilitate short-term investments, enhance short-term maturity of investment assets and promote liquidity trading in the financial markets. They are catalysts for a healthy development and growth of an economy. The role of money market instruments in financial deepening cannot therefore, be overemphasized.

Conventionally, transactions in the money market are effectuated through money market instruments principally for short-term investments. These money market instruments include Treasury bills, Commercial papers, Certificate of deposits and Bankers' acceptances, among others. By providing appropriate instruments for liquidity and trading, the money market often permits refinancing of short and medium term positions and facilitates the mitigation of business liquidity risks (Ehigiamusoe, 2013). Ezirim (2005) asserts that money market instruments are largely represented by documents of short term maturities indicating claims and obligations among economic units, which are used to intermediate funds from the surplus units of the economy to the deficit unit with maturities of one year or less. Buttressing this further, Mohammed (2014) avers that money market instruments are very liquid and seen as extra ordinarily safe. Money market facilitates financial intermediation and money supply. When money supply is increased, there is likely access to short term investment funds, thus leading to a rise in the issuance of money market instruments by surplus units.

In developing countries, researchers like Ehigiamusoe (2013); Okpe (2013); Agbada \& Odejimi (2015); Iwedi \& Igbanibo (2015); Igbinosa and Orobator (2016); Pavtar (2016); and Etale and Ayunku (2017) have 
empirically examined money market instruments in relation to economic growth, liquidity as well as the determinants of money market instruments. However, not much seem to have been done to empirically examine money market instruments and financial deepening in Nigeria. Iyiegbuniwe (2005) noted that the money market through the high liquidity of the instruments has made good improvement in breadth and trading volume since the deregulation of the financial system in 1986. Etale and Ayunku (2017) have emphasized that the money market in Nigeria still needs to be deepened to achieve the required vibrancy. While there may be assertions theoretically that money market instruments engenders financial deepening; there appears to be dearth of empirical evidences on the link between money market instruments and financial deepening in the context of Nigeria

For instance, the empirical investigation by Etale and Ayunku (2017) reported that the Nigerian money market is still very shallow as it lacks depth and breadth. They suggested that appropriate policies be employed by the federal government of Nigeria that would strengthen and deepen the money market. Karimo and Ogbonna (2017) investigated financial deepening and economic growth nexus in Nigeria with regard to supply - leading or demand - following for the period 1970 to 2013. The study used the Toda - Yamamoto augmented granger causality test. The result shows that financial deepening leads to growth and not growth leading to financial deepening. Against this backdrop, this study is undertaken to empirically determine the impact of money market instruments on financial deepening in Nigeria. Following this, the objectives of the study are to examine the relationship between treasury bills and financial deepening; investigate the effect of bankers' acceptances on financial deepening; determine if certificate of deposits impacts on financial deepening and ascertain the nexus between commercial papers and financial deepening in Nigeria.

\section{Literature Review}

\subsection{Conceptual Analysis}

Money market instruments are short-term credit instruments of high quality which encompass treasury bills, treasury certificates, bankers' acceptances, commercial papers, eligible development funds, certificate of deposits, among others (Ndugbu, Duruechi \& Ojiegbe, 2016). As part of fund and liquidity management strategies, money market instruments enable banks to meet liquidity short falls in deposit and loan demands (Ebhodaghe, 2015). Money market is a market in which short term and medium term funds are bought and sold. The money market is not a fixed geographical location like the commodities market and stock exchange market transactions. The money markets are conducted online and executed via modern telecommunication platforms.

The major participants in the money market include the deposit money banks, governments, corporations, enterprises, money market mutual funds, the Central Bank of Nigeria, pension funds among others (Ndugbu et al., 2016). Financial institutions including banks, pension funds and insurance companies are market participants and investors in money market instruments usually issued to government and large corporate organizations such as manufacturing companies who are in need of funds to execute their various programs and projects. Money market instruments play a key role in banks' liquidity management. They provide liquidity trading; allow the refinancing of short and medium terms positions which facilitates the mitigation of liquidity risks. These participants use the money market instruments to trade with very minimal risk though with low return. Money market instruments also serve as key short term liquidity management tools for other financial institutions like insurance companies.

Money market instruments are documents of short - term maturities evidencing claims and obligations among economic units, which are used to mobilize funds from the surplus units of the economy to the deficit units of the economy, thus promoting financial intermediation (Ndugbu et al., 2016). They posit further that money market instruments are used by intermediary agents especially banks to bridge financial gaps or disequilibrium in an economy. Timothy and Robert (1993) stressed that money market instruments enable borrowing and lending for periods of a year or less and also facilitate the transfer of large sums of money quickly at a low cost from one economic unit such as banks, business, government and others to another for relatively short periods of time. They are characterized by high degree of safety of principal and are most commonly issued in units of millions of naira or other currencies and some of them yield interest at maturity and are generally exempted from government income taxes, which makes them particularly attractive to investors in high income tax bracket. A good example is treasury bills. Other money market instruments apart from treasury bills are commercial papers, bankers' acceptances, certificate of deposits, among others. These money market instruments interplay to influence financial deepening in other nation's financial system.

Financial deepening is otherwise referred to as money market developments. Financial deepening is the ratio of money supply to gross domestic product. It seeks to establish how the supply leading side of money contributes to the development in the financial markets of the financial system and ultimately the growth of the economy. Conventionally the higher the money supply, the more accessible to funds by investors for investments. Investments in turn enhance productivity and economic activities, thus leading to increase in gross domestic product. However the financial market comprise of both the capital and money markets with their respective instruments of trading which boost the volume of economic activities, hence the gross domestic product (GDP). Examples of capital market instruments include shares and bonds while treasury bills, treasury certificates, 
commercial papers, bankers' acceptances, among others are money market instrument. They are all influenced by the stock of money supply and promote investment, liquidity with minimal risk and economic growth. These have implications for financial deepening of the financial system.

Financial deepening may be regarded as the ability of the financial system to supply funds to the government and the private sectors (Caballero \& Krishna-Murthy, 2004). Adequate financial deepening therefore suggests that a nation's economy has good financial instruments, institutions and possesses the ability to provide short term financial intermediation for rapid economic growth. Financial deepening is also regarded as financial depth. Financial deepening shows the level of development of financial markets by way of efficiency of financial intermediation (Honohan, 2004). Klein and Olive (2008) noted that the greater the financial deepening, the more significant is the ability of the financial sector to reallocate financial resources in support of economic development Mirkin, Kuznetsova \&Kuznetsov (2013) aver that financial deepening reflects the compatibility between the volume of production and the size and structure of the financial sector in terms of savings, investments and redistributive mechanisms particularly via financial instruments. Hence, this study seeks to empirically examine the influence of money market instruments on financial deepening, measured as the ratio of money supply to gross domestic product.

\subsection{Empirical Review}

Empirical studies involving the impact of money market instruments on financial deepening have not gained ascendancy in the context of Nigeria. Several researches have examined how money market instruments influence investments, economic growth, as well as the determinant of money market instrument with inclusive results. The relationship between money market instruments and financial deepening appears to lack sufficient empirical evidences in Nigeria. For instance, Okoro, Nwadike and Kalu (2017) examined interest rate and investment in money market instruments in a developing economy of Nigeria. The study used the quasi-experimental and analytical method using secondary data drawn from the Central Bank of Nigeria statistical bulletin covering the period 1981 to 2014. Basic descriptive statistics were used to explore the data characteristics while linear association was tested using the bi-variate correlation metrics. Similarly, the ordinary least squares regression was used as estimation method. The finding indicates that interest rate was positive and significant on money market instruments like treasury bills and commercial papers.

Etale and Ayunku (2017) sought to investigate if money market spurs economic growth in Nigeria through granger causality approach. The study used money market instruments like treasury bills (TBs), commercial papers (CPs) and bankers' acceptances (BAs) as proxy for money market while gross domestic product (GDP) was used as a proxy for economic growth. Time series data were collected from Central Bank of Nigeria statistical bulletin and the National Bureau of statistics for the period 1989 - 2014. Estimation techniques used to analyze the data include the Augmented Dickey Fuller (ADF) test, ordinary least square multiple regression and granger causality test. Findings indicate strong evidence that treasury bills and commercial paper had positive and significant influence on GDP, while bankers' acceptances (BAs) had positive but insignificant influence on GDP in Nigeria. The granger causality test results show no directional causality relationship between treasury bills, commercial papers and gross domestic product. A bi-directional relationship was observed flowing from commercial papers (CPs) to treasury bills (TBs) and bankers' acceptances (BAs) and was statistically significant at 5\% level. The researchers recommend that for the money market to influence meaningful economic growth and development in Nigeria, appropriate policies should be employed to strengthen and deepen the market.

Pavtar (2016) examined the relationship between money market and economic growth in Nigeria using time series data for the period 1985 to 2014 collected from the Central Bank of Nigeria (CBN) statistical bulletin. The author used treasury bills (TBs), treasury certificates (TCs), commercial papers (CPs) and certificate of deposits (CDs) as proxy for money market while gross domestic product (GDP) was employed as proxy for economic growth. The research used the ex-post facto research design. The descriptive statistics and ordinary least square multiple regression technique were used to analyze the data. The study findings reveal that treasury bills (TBs), treasury certificates (TCs) and commercial paper (CPs) had no significant effect on gross domestic product but certificate of deposits (CDs) had significant impact on GDP. Ajao and Festus (2011) undertook a study in two separate time periods, 2000 to 2005 and 2006 to 2009 involving the financial markets and money market instruments. Treasury bills (TBs), commercial papers (CPs), bankers' acceptances (BAs), certificate of deposits (CDs) were used as explanatory variable while the ratio of money supply to GDP was used as proxy for financial market deepening. The study used the ordinary least square multiple regression technique to analyze the data. The findings revealed that the independent variables impact positively on financial market deepening in Nigeria. Agbada and Odejimi (2015) examined the impact of money market instruments on economic viability of Nigeria for the period 1981 to 2011 using ordinary least square multiple regression technique to analyze the data. Treasury bills (TBs), treasury certificates (TCs); certificate of deposits (CDs), commercial papers (CPs) and bankers' acceptances (BAs) were used as explanatory variables. The study finding indicates a positive linear relationship between the dependent variable (economic viability) and independent variables. The study did recommend that 
monetary authorities need to come up with policies to boost money market operations and also to be proactive in their surveillance role in order to check practices that are capable of sabotaging market deepening and soundness. Antwi, Atta Mills and Zhao (2012) carried out an empirical analysis of the performance of the Ghana Stock Exchange and treasury bills for the period 1990 to 2010. Obviously the finding reveals that Ghana all-share index had higher risk and higher return compared to treasury bills.

Igbinosa and Orobator (2016) empirically investigated the determinants of money market development in Nigeria. They sought to know which money market instrument significantly determine money market development for the period 1981 to 2013. Specifically, the study examined the effect of money market instruments such as treasury bills, certificate of deposits, bankers' acceptances and commercial papers on money market development in Nigeria for the period 1981 to 2013. The study employed the augmented dickey fuller test to determine the stationarity of the variables. The Johansen and Juselius co-integration and error correction mechanisms (ECM) techniques were used to establish the short and long run relationships among the determinants of money market development in Nigeria. The findings indicate that certificate of deposits and commercial papers and treasury bills majorly determine the development of money market in Nigeria.

Ndugbu, Duruechi and Ojiegbe (2016) examined the relationship between money market instruments and bank performance in Nigeria for the period 1990 to 2014 based on the data from the Central Bank of Nigeria statistical bulletin, the ordinary least square multivariate regression method, granger causality test, the Johansen and Juselius co-integration test and the error correction mechanism method. Their results reveal that treasury bills, and commercial papers have positive and significant relationship with bank performance in Nigeria, while bankers' acceptances has a negative relationship with bank performance. The researcher deduced from the study that the influence of the money market instruments on bank performance promote bank ability to increase money supply through effective monetary policy of the monetary authority, enhance economic activities and by extension positively contribute to financial deepening. The study thus conjectures that money market instruments do not directly contribute to financial deepening in Nigeria.

McDonald and Schumater (2007) investigated the role of creditor rights and information sharing in explaining why some financial markets in sub-Saharan Africa have remained shallow for the period 1983 to 2004. They used ordinary least square multivariate regression method to analyze the data. The study finds that while financial liberalization and macroeconomic stability promote financial deepening, they are not enough. For countries with similar financial liberalization efforts, those with stronger legal institutions and information sharing have deeper financial development. This result is consistent with a growing body of research for other regions of the world.

\section{Methodology}

This study focuses on money market instruments and financial deepening in Nigeria. The Ex-post facto and longitudinal research designs are used. The data were collected from the Central Bank of Nigeria statistical bulletin (2017), covering a period of twenty seven (27) years, 1981 to 2016, since the post structural adjustment period, including periods of various financial reforms in this industry to date. Preliminary tests such as Augmented Dickey Fuller (ADF) test, unit root test, correlation statistics, granger causality test and Johansen \& Juselius co-integration technique were first conducted prior to the main estimation methods of ordinary least square multiple regression and the error correction mechanism (ECM) techniques. The Augmented Dickey Fuller (ADF) test is necessary to determine the stationarity of time series data in order to avoid spurious result regression (if any). The granger causality helps to determine the direction of causality between the independent variables (money market instruments) and the dependent variables (financial deepening). The correlation statistic shows the degree of association among variables. The association could be negative or positive, weak or strong. The ordinary least square multivariate regression technique is used to determine the long-term impact of explanatory variables on the dependent variable. The choice of the ordinary least square in researches is premised not only on its computational accuracy and simplicity, but also as a result of its optimal properties vis-à-vis best linear unbiased estimator, which also includes minimum variance, zero mean value of the random terms (Koutsoyiannis, 2003 and Gujaratis, 2004). The Johansen co-integration technique and error correction mechanism were employed to determine the long and short run relationships between money market instruments and financial deepening. Specifically, the error correction mechanism (ECM) specifies the speed at which short - run disequilibrium can be corrected in the long - run in terms of the relationship between dependent variable and explanatory variables (Ndugbu et al., 2016).

\subsection{Model Specification}

This study adapts the empirical models of Igbinosa and Orobator (2016), Karimo and Ogbonna (2017), Etale and Ayunku (2017). The functional form of the model is:

This study adapts the empirical models of Igbinosa and Orobator (2016), Karimo and Ogbonna (2017), Etale and Ayunku (2017). The functional form of the model is: Financial deepening = $f$ (Treasury bills, Bankers acceptances, commercial papers, certificate of deposits)........(1) That is, fdp $=(\mathrm{TBs}, \mathrm{BAs}, \mathrm{CPs}, \mathrm{CDs})$ 
The model is stated in stochastic form as:

$f d p_{t}=\beta_{0_{t}}+\beta_{1} T B_{s_{t}}+\beta_{2} B A_{s_{t}}+\beta_{3} C P_{s_{t}}+\beta_{4} C D s_{t}+\varepsilon$

Where:

fdp = Financial deepening, proxy by broad money supply divided by gross domestic product and is the (dependent variable) of the model; and the independent variables are:

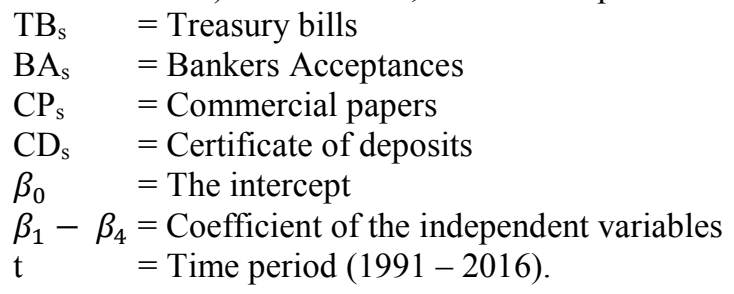

\subsection{Apriori Expectation}

Apriori expectation from the above model is expressed as $\beta_{1}, \beta_{2}, \beta_{3}, \beta_{4}>0$; this connotes that a positive relationship is expected to exist between the independent variables of the model and the dependent variable.

\subsection{Empirical Analysis}

The results of the various analyses based on specified estimation methods are presented below:

Table 1: Summary of unit root test at level

\begin{tabular}{|l|l|l|}
\hline Variables & ADF statistics & T-critical values \\
\hline FDP & -4.1409 & -2.9677 \\
\hline TBs & -3.5640 & -2.9540 \\
\hline Bas & -7.2032 & 2.9677 \\
\hline CPs & -10.6422 & -2.9810 \\
\hline CDs & -4.7876 & -2.9484 \\
\hline
\end{tabular}

Source: Author's computation, 2019 from E-view 8.0

The table 1 above shows the Augmented Dickey Fuller statistics test result. It can be seen that the ADF test statistics are all greater than the test critical values at 5\% significant level. Therefore, all the variables are stationary at level.

Table 2: Correlation statistics Results

\begin{tabular}{|l|l|l|l|l|l|}
\hline Variables & FDP & TBs & CDs & Bas & CPs \\
\hline FDP & 1 & & & & \\
\hline TBs & 0.393 & 1 & & & \\
\hline CDs & 0.402 & 0.497 & 1 & & \\
\hline Bas & 0.343 & 0.613 & 0.098 & 1 & \\
\hline CPs & 0.390 & 0.489 & 0.176 & 0.493 & 1 \\
\hline
\end{tabular}

Source: Researcher's computation 2019 from E-view 8.0 version.

Table 2 above is the Pearson coefficient of financial deepening and money market instruments. It can be observed that FDP and TBs are positively correlated $(\mathrm{r}=0.393)$. Certificate of deposits and financial deepening are strongly and positively associated $(\mathrm{r}=0.402)$. Bankers' acceptances and FDP are positively related $(\mathrm{r}=0.343)$ while commercial paper and financial deepening are positive and strongly related $(\mathrm{r}=0.390)$. Treasury bills and certificate of deposits are positively correlated $(\mathrm{r}=0.497)$; Treasury bills and bankers' acceptance are strongly related $(\mathrm{r}=0.613)$ while commercial papers and Treasury bills are aslo positively associated $(\mathrm{r}=0.489)$. While certificate of deposits is weak and positively related with Bankers' acceptance $(r=0.098)$, it is however positive and weakly associated with commercial papers $(\mathrm{r}=0.176)$; bankers' acceptance is positively related with commercial papers $(\mathrm{r}=0.493)$. The result clearly affirms the outcome of variable inflation factor (VIFs), in table 2. The correlation coefficients do not in any way show signs of perfect multicollinearity and all the variables reinforce in a mutual perspective. Except for both BAs and TBs that are highly correlated $(r=0.613)$, both independent variable. This may lead to serial correlation in the analysis. To avoid this disturbance, we can afford to drop one in place of the other. 
Table 3: Granger causality test (Lags: 2)

\begin{tabular}{|l|l|l|l|}
\hline Null Hypothesis & OBS & F-statistic & Prob \\
\hline TB does not granger cause FDP & 34 & 45.865 & 1.009 \\
FDP does not granger cause TB & & 1.579 & 0.223 \\
\hline CD does not granger cause FDP & 34 & 4.785 & $0.016^{*}$ \\
FDP does not granger cause CD & 34 & 6.061 & $0.000^{*}$ \\
\hline BA does not granger cause FDP & & 7.881 & 1.011 \\
FDP does not granger cause BA & 34 & 13.717 & $0.001^{*}$ \\
\hline CP does not granger cause FDP & & 4.470 & 6.005 \\
FDP does not granger cause CP & 34 & 1.633 & $0.020^{*}$ \\
\hline CD does not granger cause TB & & 4.809 & 0.212 \\
TB does not granger cause CD & 34 & 17.470 & $0.015^{*}$ \\
\hline BA does not granger cause TB & & 17.319 & 1.005 \\
TB does not granger cause BA & 34 & 12.470 & 1.005 \\
\hline CP does not granger cause TB & 34 & 3.794 & 0.000 \\
TB does not granger cause CP & & 1.270 & $0.034^{*}$ \\
\hline BA does not granger cause CD & 34 & 2.338 & 0.296 \\
CD does not granger cause BA & & 4.609 & 2.005 \\
\hline CP does not granger cause CD & 34 & 0.400 & 0.114 \\
CD does not granger cause CP & & 0.191 & $0.018^{*}$ \\
\hline CP does not granger cause BA & & 0.673 \\
BA does not granger cause CP & & 0.826 \\
\hline
\end{tabular}

Source: Author's computation, 2019 from E-view 8.0 version. The * represents significant at 5\% level

Table 3 above reveals that there is neither bi-directional nor unidirectional causality from TBs to FDP; FDP to TBs; BAs to TBs; TBs to BAs; BAs to CD, CD to BAs, CP to BAs, BAs to CP and they were not all statistically significant at 5\% level. Of essence is the fact that Treasury bills do not cause financial deepening and is not significant in the Nigerian financial markets. Assessment of the other money market instruments points out that there is bi-directional causality between certificate of deposit and financial deepening and was statistically significant in the reference period. Increase in fixed deposit by bank customers should promote accessibility to finance for short - term investment and deepening of the financial market in the Nigerian context; assuming all factors are held constant. While BAs does not granger cause FDP. FDP however granger causes BA and also FDP granger cause CP in a unidirectional manner and is statistically significant. The tendency for bankers' acceptances to cause financial deepening in Nigeria is dependent on investment level, which of course is a function of access to cash from the bank, assuming deposit increase policy by the apex bank. For bankers' acceptances to induce financial deepening, a good and trusted relationship must exist between an investor (bank customer) and the bank. A unidirectional causality flows from financial deepening to commercial papers and is statistically significant at 5\% level. Similarly, unidirectional causality runs from Treasury bills (TBs) and certificate of deposits (CDs); certificate of deposits (CDs) and commercial papers (CPs) and was statistically significant at 5\% level. However, bi-directional causality flows from CPs to TBs; and from TBs to CPs and were statistically significant at 5\% level. On the overall, this research establishes that money market instruments granger cause financial deepening in the context of Nigerian financial market except the case of TBs that granger cause FDP while in general, FDP granger cause money market instruments. However, financial deepening of the financial market also has the propensity to induce effectiveness and volume of the money market instruments, thereby enhancing the growth of the Nigerian economy.

Table 4: Descriptive Statistics Result

\begin{tabular}{|l|l|l|l|l|l|}
\hline Statistics & FDP & TB N'000 & CD N'000 & BA N'000 & CP N'000 \\
\hline Mean & 20.929 & 508666.80 & 3621.647 & 30416.95 & 126400.6 \\
\hline Maximum mean & 67.480 & 2922927 & 50500.00 & 347681.0 & 1276544.0 \\
\hline Std..Dev & 11.589 & 614085.8 & 11228.86 & 59907.53 & 261041.5 \\
\hline Jarque-Bera & 753.460 & 13.421 & 186.407 & 722.371 & 199.657 \\
probability & $(0.000)$ & $(0.001)$ & $(0.000)$ & $(0.000)$ & $(0.000)$ \\
\hline
\end{tabular}

Source: Researcher's computation from E-view 8.0 version.

Table 4 shows that the average financial deepening rate was $20.92 \%$ in the period observed. The Jarque-Bera value of $753.460(p=0.000)$ is statistically significant at $1 \%$ level and was normally distributed. The average Treasury bills in the reference period amount the N508666.80 million. Its Jarque-Bera value of $13.421(\mathrm{p}=0.001)$ is statistically significant at 5\% level. The average value of certificate of deposits was N3621.677 million. The Jarque-Bera value of $186.407(\mathrm{p}=0.000)$ is statistically significant at 5\% level. Bankers' acceptances average value was N30416.95 million. The Jarque-Bera of $722.371(\mathrm{p}=0.000)$ is statistically significant at $5 \%$ level. 
Commercial papers average value was N126400.6 million, the Jarque-Bera value of $199.657(\mathrm{p}=0.000)$ was statistically significant at 5\% level. This implies that the value of commercial papers as one of the money market instruments has increased in Nigeria, thus leading to financial deepening under the reference period in this study.

Table 5: Ordinary Least Square Multivariate Regression Result

Dependent variable: FDP

\begin{tabular}{|l|l|l|l|}
\hline Variables & Coefficient values & T-values & Prob. Values \\
\hline C & 7.717 & 0.736 & 0.467 \\
\hline TBs & -4.910 & -2.507 & $0.018^{*}$ \\
& {$[-2.507]$} & & \\
\hline CDs & 9.970 & 1.647 & 0.100 \\
& {$[1.647]$} & & \\
\hline Bas & -3.690 & -1.413 & 0.168 \\
& {$[-1.413]$} & & 0.628 \\
\hline CPs & 2.670 & 0.489 & \\
& {$[0.489]$} & & \\
\hline R-squared & $=0.850$ & & \\
Adjusted R-square & $=0.823$ & & \\
F-statistic & $=31.800 \quad 0.000$ & & \\
Durbin - Watson statistic & $=1.925$ & & \\
\hline
\end{tabular}

Source: Researcher's computation from E-view 8.0 version

The table 5 above shows that the coefficient of determination (R-squared) is about $85 \%$, leaving $15 \%$ unexplained due to stochastic error term. The adjusted R-squared reads $82 \%$, leaving $18 \%$ unexplained due to error term. The F-statistics of $31.800(\mathrm{P}=0.000)$ indicates that a linear relationship exist between FDP and the independent variables in the model. The individual coefficient value indicates that Treasury bills (TBs) is negatively related to (-4.910) financial deepening and is significant at $5 \%$ level in the long-run. Both certificate of deposit and commercial papers exert positive impacts $\left(\beta_{1}=9.970\right)$ and $\left(\beta_{2}=2.670\right)$ on financial deepening in the long-run in Nigeria and were statistically not significant at $5 \%$ levels, Bankers acceptance exerts negative effect (-3.690) on financial deepening in the long-run and is not statistically significant. The Durbin-Watson statistics of 1.925 indicates the absence of auto correlation problem in the regression result; thus making the result useful for policy direction.

Table 6: Co-integration analysis

\begin{tabular}{|l|l|l|l|l|}
\hline Hypothesis & Trace statistics & Critical value at 5\% & Maximum Eigen value & Critical values at 5\% \\
\hline $\mathrm{R}=0$ & 155.939 & 69.818 & 80.497 & 33.876 \\
\hline $\mathrm{R} \leq 1$ & 75.442 & 47.856 & 42.220 & 27.584 \\
\hline $\mathrm{R} \leq 2$ & 33.222 & 29.797 & 21.676 & 21.131 \\
\hline
\end{tabular}

Source: Researcher's computation, 2019 from E-view 8.0 version

The Johansen co-integration result above indicates that there exist least (3) co-integration equations under the trace statistics value and maximum Eigen value statistic and were statistically significant at 5\% $(0.05)$ level. It suggests the existence of long-run relationship between money market instruments and financial deepening in Nigeria.

Dependent variable: FDP

Table 7: Error Correction Model (ECM) Estimates

\begin{tabular}{|l|l|l|l|}
\hline Variable & Coefficient & Statistic & P-value \\
\hline C & 1.747 & 2.516 & 0.018 \\
\hline DBA(-1) & -7.440 & -6.234 & 0.000 \\
\hline DCD(-1) & -9.680 & -1.725 & 0.095 \\
\hline DCP & 1.710 & 0.323 & 0.749 \\
\hline DTB & -1.940 & -0.073 & 0.941 \\
\hline ECM(-1) & -7.640 & -3.429 & 0.002 \\
\hline R-squared & -0.137 & 0.842 & 0.407 \\
Adj. R-squared & $=0.704$ & & \\
F-statistic & $=0.639$ & & \\
F- (prob-statistic) & $=10.737$ & & \\
Durbin Watson statistic & $=0.000$ & & \\
\hline
\end{tabular}

Source: Researcher's computation from E-view 8.0 version, 2019

The result in table 7 above shows that the adjusted coefficient of determination reads about $0.639(63.9 \%)$.

This means that the explanatory put together determine financial deepening in Nigeria in the short-run and was 
statistically significant given the f-statistic of $10.737(\mathrm{p}=0.000)$. The error correction mechanism $(\mathrm{ECM})$ lagged one period is low but appropriately signed at 5\% level. It indicates that short-run disequilibrium in financial deepening is corrected at a speed of approximately $14 \%$ per annum (13.7\%). The individual coefficients show that lagged one period of bankers acceptance is negative (-7.440) on financial deepening and is statistically significant in the short - run. Lagged one period of certificate of deposits, DCD (-1) exerts a negative effect $(-9.680)$ on financial deepening and is not significant except at $10 \%$. Commercial paper is observed to have negative impact $(-1.940)$ on financial deepening and is not significant at 5\% level in the short - run in Nigeria. Treasury bills exert a negative impact (-7.640) on financial deepening in Nigeria and is significant at 5\% level. The Durbin-Watson statistic of 1.906 is closer to 2 . This portends that there is no significant autocorrelation in the model, thus making the empirical result useful for policy purpose.

The results from the ordinary least squares, error correction mechanisms analysis and granger causality test are quite intriguing in this study. For instance, Treasury bills exerted positive and significant effect on financial deepening and were statistically significant both in the short- and long- runs. Certificate of deposits positively impacted on financial deepening and was not significant both in the short- run and long - run. In the long - run, bankers' acceptance impacted on financial deepening and was not significant. Commercial papers impacted positively on financial deepening and were not significant. In the short-run, one period lag of bankers' acceptances and certificate of deposits exerted negative relationships with financial deepening and were not significant. The causality test result shows bi-direction causality between certificate of deposits and financial deepening in Nigeria. Both Treasury bills and certificate of deposits have uni- directional causality. While Treasury bills has unidirectional causality with commercial papers, financial deepening was found to granger cause both certificate of deposits and commercial papers in uni- direction in the context of Nigeria.

Therefore, compared with the money market in some developed countries of the world, the overall implication of the results portend that the Nigerian money market is still at the emerging state. Overtime, several instruments are used by investors and participants to trade in the money market in Nigeria. These money market instruments are expected to promote short-term investments and economic activities and by extension financial market deepening in the context of Nigeria. For instance, the study finds long- and short- run positive relationships between money market instruments such as Treasury bills, certificate of deposits and commercial papers and financial deepening. While Treasury bills are significant, certificate of deposits and commercial papers are not significant towards financial deepening. This is affirmed by the existence of causality between Treasury bills and financial deepening as well as among the other money market instruments (that is certificate of deposits, bankers' acceptances and commercial papers) investigated in this study. It clearly suggests that the while Treasury bills enhance financial deepening, the volumes and values of certificate of deposits and commercial papers are not translating to financial deepening in Nigeria. Bankers' acceptances and certificate of deposits have inverse relationship with financial deepening in the short - run in the context of Nigeria. Similarly, while the study establishes a long- run impact of money market instruments on financial deepening, granger causality also flows bi-directionally between money market instruments and financial deepening in the context of Nigeria. The finding is in consonance with Ajao and Festus (2011), Igbinosa and Orobator (2016), Ndugbu et al. (2016). It is not in tandem with Ehigiamusoe (2013) and Etale and Ayunku (2017). Specifically, this study finds that Treasury bills do not granger cause financial deepening. Treasury bills exert a negative impact in the long - run and short - run on financial deepening in Nigeria, which is however significant. The negative effect of Treasury bills on financial deepening may not be unconnected with the low volume and value traded in the money market. Another reason adduced for this inverse relationship may be the weak monetary policy by the apex bank over time and weak framework. The finding agrees with the research outcome by Ajao and Festus (2011); Igbinosa and Orobator (2016); Partar (2016); Etale and Ayunku (2017) and Karimo and Ogbonna (2017). It however disagrees with the researches of Iyiegbumiwe (2005); Agbada and Odejimi (2013); Ndugbu et al. (2015); and Okoro et al. (2017). Thus, this research has contributed to existing literature that money market instruments cause financial deepening in the context of Nigeria.

\section{Conclusion and Recommendations}

The conclusion of this study is that money market instruments like Treasury bills, bankers' acceptances, certificate of deposits and commercial papers promote financial deepening both in the short-run and long-run in a developing economy like Nigeria. The study found strong effect of money market instruments on financial deepening in Nigeria in the long run. Premised on these pertinent findings, this study recommends that the monetarist has to regularly float high volume of treasury bills and other money market instruments to come up with efficient and effective monetary policies with a view to engendering financial deepening and acceleration of economic activities in Nigeria. Policies that promote trading in international money market instruments like bankers' acceptances should be strengthened by the Federal government of Nigeria to deepen the financial market as well as enhance the competitiveness of the Nigerian money market in the global market. This should consequently translate to financial deepening in Nigeria and improvement of the economy at large. 


\section{References}

Agbada, A.O., \& Odejimi, D. O. (2015). Developments in money market operations and economic growth viability in Nigeria: An empirical analysis. European Journal of Business and Management, 7(18), 42-52.

Ajao, M.G., \& Festus, B.O. (2011).Appraisal of the effect of the global financial meltdown on the Nigerian money market.International Journal of Economics and Finance, 3(4), 95-105.

Antwi, S., Atta Mills, E., \& Zhao, X. (2012). An empirical analysis of the performance of the Ghana stock exchange and treasury bills. International Journal of Business and Social Science, 3(23), 97-107.

Caballero, R.J. \& Krishna-Murthy, A. (2004). Exchange rate volatility and the credit channel in the emerging markets: Vertical Perspective. Massachusetts Institute of Technology, Department of Economics Working Paper No 04-24.

Ebhodaghe, J.U. (2015). Liquidity management in Nigerian Banking. The Nigerian Observer.

Ehigiamusoe, U.K. (2013). The link between money market and economic growth in Nigeria - Vector error correction model approach. International Journal of Social Education, Economics and Management, 7(12), 1792-1800.

Etale, L.M., \& Ayunku, P.E. (2017). Does money market spur economic growth in Nigeria? Granger causality approach. International Journal of Development and Economic Sustainability, 5(7), 28-37.

Ezirim, C.B. (2005). Finance dynamics, principles, techniques and application. Port Harcourt. Markowitz Centre for Research and Development.

Gujaratis, D.N. (2004). The theory of economics, West Point McGraw Hill.

Honohan, P. (2004). Financial development, growth and poverty: how close are the links? World Bank Development Research Group, finance and financial sector operations and policy department. Available at: $<$ http:??www.microfinancegateway.org/sm/document-1.9.26333/211/13-wps3203.pdf.

Igbinosa, S.O., \& Orobator, B. (2016). Determinants of money market development in Nigeria: Empirical evidence. Journal of Business and Value Creation, 2(3), 11-24.

Iwedi, M. \& Igbanibo D.S. (2015). The nexus between money market operations and economic growth in Nigeria: An empirical investigation. International Journal of Banking and Finance Research, 1(2), 1-17.

Iyiegbuniwe, W.I.C. (2005). The Nigerian money market: Evolution and structure In Fakiyesi, O.O. and Akano, S.O. (eds) Issues in Money Finance and Economic Management in Nigeria, Lagos, University of Lagos.

Johansen, S. \& Juselius, K. (1990). Maximum likelihood estimation and inference on co-integration with applications to the demand for money. Oxford Bulletin of Economics and Statistics, 52(2), 169-210.

Karimo, F.M., \& Ogbonna, O.E. (2017). Financial deepening and economic growth nexus in Nigeria: supply lading or demand - following. Economies, 5(4), 1-18.

Klein, M.W., \& Olive, G.P. (2008). Capital account liberalization, financial depth and economic growth. Journal of International Money and Finance, 27(6), 861-875.

Koutsoyiannis, A. (2003). Theory of econometrics $2^{\text {nd }}$ Edition Palgrave Macmillan Publishers.

McDonald, C., \& Schumater, L. (2007). Financial deepening in sub-Saharan Africa: Empirical evidence on the role of creditor rights protection and information sharing. IMF Working Paper, WP/07/203.

Mohammed, A.H. (2014). Money market instrument in Bangladesh. Published in Education.

Mirkin, Y., Kuznetsova, O. \& Kuznetsov, A. (2013). The financial depth of emerging markets: the case of Russia. Journal of Competition and Change, 17(2), 156-175.

Ndugbu, M.O., Duruechi, A.H., \& Ojiegbe, J.N. (2016).Money market instruments and bank performance in Nigeria. Journal of Economics and Sustainable Development, 7(10), 95-103.

Okoro, E.U., Nwadike, A.O., \& Kalu, E.U. (2017). Interest rate and investment in money market instruments in a developing economy: A case of Nigeria. Journal of Economics, Management and Trade, 20(2), 1-9.

Okpe, I.I. (2013). Money market on the Nigerian economic development. Journal of Economics and Sustainable Development, 4(5), 5.

Pavtar, A. (2016). The nexus between money market instrument and Nigeria's economic growth: A time series analysis. Journal of Accounting and Financial Management, 2(3), 22-39.

Timothy, Q.C. \& Robert, K.I. (1993). The money market. Federal Reserve Bank of Richmond. 